Acta Poloniae Historica

110,2014

PL ISSN 0001-6892

Stanislav Holubec

\title{
A 'GOLDEN TWENTY YEARS', OR A BAD STEPMOTHER? CZECH COMMUNIST AND POST-COMMUNIST NARRATIVES ON EVERYDAY LIFE IN INTERWAR CZECHOSLOVAKIA
}

\begin{abstract}
The article deals with the narratives on the First Czechoslovak Republic in the Czech communist and post-communist public discourse. It is argued that the attitude to the First Republic played an important role in the political history of the Czech society in the second half of the twentieth century. The article shows that the negative narratives on this period were of key importance for the legitimisation of the communist regime whilst the positive narratives were an essential component in the discourse of anti-communists, supporters of the democratic reforms and the dissident movement in the 1970s and 1980s. The 1989 revolution was interpreted both as the return to the success of the First Republic democracy and economic system, and as the imagined return from the East to the West.
\end{abstract}

Keywords: First Czechoslovak republic, communism, Post-communism, narratives, historical memory

\section{I \\ INTRODUCTION}

The 'Golden Twenty Years' narratives of the post-communist period and the contemporary Czech Republic can be divided into sub-narratives. The two most important seem to be 'the island of democracy' and its 'economic performance'. ${ }^{1}$ The island of democracy argument contains the claims that it was a country where "all the nations were

${ }^{1}$ On the contrary, in the historical memory on the Habsburg monarchy, its economic performance does not seem to play any substantial role. This is surprising because, in economic terms, the period 1880-1914 was far more successful for Bohemia than the whole of the twentieth century, including the First Republic. 
equal" whereas "the whole world was envious of President Masaryk, a real philosopher on the throne". The 1925 statement from his admirer, G.B. Shaw, that he would be the "natural choice to serve as the president of Europe, had it united", ${ }^{2}$ is commonly repeated. The diplomatic skills of his minister of foreign affairs and successor Edvard Beneš are characterised as "so great that he would turn this state into a great power, had it been bigger than as small as Czechoslovakia is".

The narrative of Czechoslovak economic development contains sub-narratives such as: "the world's tenth most developed country"; "the world-famous shoe company Bata"; "Slovakia and, especially, Subcarpathian Ruthenia saw a real development", and "all are thankful there until today for what the Czechs have done for them"; the Czech military technologies (tanks, aircrafts and machineguns) "were fully comparable to Germany's" and, to some extent, made the Nazi military expansion possible, but only after the Germans captured them. Finally even "the skilled Czech artisans and polite and accommodating personal in the Czech stores and restaurants at that time". ${ }^{3}$ However, this essay does not primarily seek to analyse the validity of positive narratives; this has already been done by other historians. ${ }^{4}$

${ }^{2}$ Andrea Orzoff, Battle for the Castle: The Myth of Czechoslovakia in Europe, 1914-1948 (Oxford, 2009), 172.

${ }^{3}$ The narrative on the successful economy still reappears in academic studies; e.g., Bradley F. Abrams claims that "The Czech lands had been the most industrialised region in the Austro-Hungarian empire and provided the foundation for an economy that became the world's tenth largest." (Bradley F. Abrams, The Struggle for the Soul of the Nation: Czech Culture and the Rise of Communism [Oxford, 2004], 118.) Czech authors claim that after 1945, "in economic terms, the Republic moved from the top ten developed countries to the backward European countries" - as in Ludmila Fialová et al., Dějiny obyvatelstva českých zemí (Prague, 1996), 337. One of the most respected recent studies on interwar unemployment bears the title 'The other side of the interwar prosperity', i.e., Jakub Rákosník, Odvrácená strana meziválečné prosperity. Nezaměstnanost v Československu v letech 1918-1938 (Prague, 2008).

${ }^{4}$ Czech historians Jaroslav Pátek and Eduard Kubů have problematised this narrative in their book Mýtus a realita hospodárské vyspělosti Československa mezi světovými válkami (Prague, 2000). President Masaryk' policies and his myth are critically analysed in Antonín Klimek, Boj o hrad: vnitropolitický vývoj Československa 1926-1935 (Prague, 1996 [and 1998]), and, more recently, in Orzoff, Battle for the Castle. The narrative on the advanced Czechoslovak army is problematised by Jan Tesař, Mnichovský complex: jeho př́ičiny a duisledky (Prague, 2000); critical studies on Slovak economic development during that time were published 
Rather than that, I would try and find out how this narrative has been constituted, how it developed and changed over time.

The narrative considering the interwar period as 'a golden twenty years' and "the only time in history in which we were really independent" exists in post-communism not only in the Czech Republic, but also in Poland, the Baltic states and Romania. ${ }^{5}$ It is weaker in Slovakia and in most of the countries of the former Yugoslavia and it is virtually nonexistent in Bulgaria and Hungary where this period is seen as the time of the deepest decline and misery. Generally, the sentiment is strong in the countries that won their independence after 1918, and in those countries which were on the winners' side in WWI and could extend their territory. 'The myth of the Golden Age'

by Václav Průcha et al., Hospodářské a sociální dějiny Československa 1918-1992 (Brno, 2004). The minorities policy has been critically analysed by numerous authors; the recent examples including: Tara Zahra, Kidnapped Souls: National Indifference and the Battle for Children in the Bohemian Lands, 1900-1948 (Ithaca, 2010); Mirek Němec, Erziehung zum Staatsbürger. Deutsche Sekundarschulen in der Tschechoslowakei (Essen, 2010); Ines Koeltzsch, Geteilte Kulturen. Eine Geschichte der tschechischjüdisch-deutschen Beziehungen in Prag (1918-1938) (Munich, 2012). The authoritarian practices in the Bata company and the closeness of its owner's ideology to fascism are the topics of the studies: Stanislav Holubec, 'Silní milují život: Utopie, ideologie a biopolitika batovského Zlína', Časopis pro kulturni dějiny Kuděj (2009), no. 2; and, Anett Steinführer, 'Stadt und Utopie, Experiment Zlín', Bohemia. Zeitschrift für Geschichte und Kultur der böhmischen Länder (hereinafter: Bohemia), xlii, 1 (2001).

${ }^{5}$ Ulf Brunnbauer, 'Introduction', in idem (ed.), (Re)Writing History: Historiography in Southeast Europe after Socialism (Münster, 2004), 24. The narrative of economic success exists not only in Czechoslovakia but also in Romania, the Baltic countries, and Poland. As Bogdan Murgescu mentions, it is striking that contrary to 'the golden twenty years' narrative, most Western historians consider the whole period as an 'economic abyss', 'an age of catastrophe', or "an era deeply disturbed by the war, depression and beggar-your-neighbour policies"; see idem, "The economic Performance of Interwar Romania: the Golden Age Myth and Statistical Evidence', Jahrbücher für Geschichte und Kultur Südosteuropas, vi (2002), 43. The statistical evidence shows that this region was not unique in terms of international trends. Statistical data indicate that even in its most developed phase, Czechoslovakia was by no means economically miraculous. and cannot be placed among the main powers of the world economy; see Josef Faltus and Václav Průcha, Hospodárské déjiny (Prague, 1992), 53-4. It was less developed than most of the Western European countries, with the possible exception of Austria or Finland. The statistical evidence also shows that during the years 1918-38, the position of Czechoslovakia deteriorated. 
of Czechoslovakia seems to be (in comparison to other countries) shared primarily not by the nationalist conservatives, but by a variety of political forces - centre-right and centre-left alike. It is partly due to the fact that the interwar Czechoslovakia remained a parliamentarian democracy with a strong influence of the centre-left parties, while other countries of the region shifted gradually to authoritarian regimes, which made them attractive mainly to the post-communist right-wing. Thus, the narrative about the 'island of democracy' exists only in Czechoslovakia, although there have been attempts in other East-Central European countries to interpret local authoritarian regimes as more democratic than commonly labelled.

There is a lot of evidence indicating that the Czech citizens of interwar Czechoslovakia mainly shared the positive picture of their own state, which they perceived as the fulfilment of a daydream lasting for three centuries. However, this Czech positive narrative was not shared by many members of the German, Slovak and other ethnic groups that accounted altogether for about a half of the population, as well as by the First Republic's communists and their voters who represented an important part of the Czechoslovak working class. For most of the Czech Germans - the biggest national minority (23\% of the population at that time) - the First Republic was rather a 'prison of nations' since the beginning - and it remained so, not only because it was established against their will but also because the new state was not willing to integrate the German minority in its structures or to provide them with autonomy. A significant part of the second largest minority, the Slovaks ( $15 \%$ of the population), did not perceive the First Republic as an 'island of democracy and prosperity', and their views on it were only slightly better than those of the Czechoslovak Germans. The majority of Slovaks condemned the Czech refusal to recognise the Slovak nation (due to their acceptance of the axiom of the Czechoslovak nation), the control over a majority of important positions in Slovakia by Czechs, the economic stagnation of Slovakia and the lower respect among Czechs towards Slovak cultural and religious traditions. The Czech communists and a portion of sympathising workers and intellectuals also tended to negatively view the First Republic as a 'bourgeois state' oppressing the workers (although in the period of the People's Front of 1935-8 their views were different), leaving aside a few Czech fascists perceiving the First Republic as the fruit of cooperation between Jews and Freemasons. The attitudes 
of the ethnic minorities partly survived in their collective memories to this day and are in sharp contrast to the prevailing positive Czech interpretations of the First Republic.

The 'First Republic myth' began unfolding shortly after the state was established in 1918. The First Czechoslovak Republic tried to actively promote itself, not only in the eyes of its citizens but also in Western countries, mainly in Britain and France. The positive image of the post-1918 period faded with time as many Czechs ceased to support their new country, which held especially true during the Great Depression. As Peter Bugge argues, in the last years before the Munich Agreement almost everybody was certain that radical reforms of Czechoslovak politics, economy and society were necessary; however, there was not enough will to take such a step. ${ }^{6}$ The 'Czech First Republic myth' was understandably strengthened in the emotionally escalated atmosphere before the Munich Agreement of 1938 and subsequently during the Nazi occupation, especially in the period of political terror (1941-2), and the years of economic misery (1943-5). The First Republic symbolised the period of national freedom and abundance, although some Czechs, workers in particular, in the first years of the Protectorate appreciated the job security, compared with the mass unemployment of the 1930s which was still in the fresh memory. Yet, the rebirth of the Czechoslovak state in 1945 was not seen as a return to the First Republic, but rather as a foundation of a new state and society without many of the well-remembered negative aspects of its predecessor (such as political corruption, a shattered political camp, social inequality, nepotism, and unemployment). A public opinion poll conducted in 1946, and for the first time based on quota sampling, placed the First Republic in the fourth place (in answer to the question "what was the most successful period in our history?"), after the Hussite period, the time of Charles IV, and the contemporary post-war era, with only 8 per cent claiming it to have been the greatest time in Czechoslovak history. ${ }^{7}$

There was one exception from the rather negative picture of the First Republic in these years - the personality of its President,

${ }^{6}$ Peter Bugge, 'Czech democracy 1918-1938. Paragon or parody?', in Bohemia, xlvii, 1 (2007), 28.

7 Štěpánka Pfeiferová and Jiří Šubrt, 'Veřejné mínění o problematice českých dějin', Naše společnost, vii, 2 (2009), 17. 
Masaryk, whose legacy was accepted by the whole political spectrum - from the Christian People's Party to the communists (the winners of the 1946 election). Masaryk himself rated in the above mentioned opinion poll as the most important personality in Czechoslovak history. ${ }^{8}$ Even communist journalists claimed that "today, Masaryk would support the people's democracy", and described the politics of nationalizing the economy as the "fulfilment of the Masaryk ideal." According to the communist journalists, it was necessary to see Masaryk's critical remarks on Marxism "in the context of their time" and, at any rate, "he found Marxism worthy of his polemics." 9 The communists, however, remained silent on the fact that Masaryk called them 'pathologic sediment' and that they even had run their campaigns under the slogan 'not Masaryk but Lenin' in 1934.

The abovementioned sociological research did not analyse which social and demographic groups had the best memories of the First Republic. We can only suppose that it was mainly the cohorts born between 1890-1910 connecting the period after 1918 with their youth. For them, October 1918 (when Czechoslovakia was established) was the crucial generational experience. Ethnically, they seemed to be Czechs and Jews rather than Hungarians or Slovaks (the Germans had already been expelled); socially, the First Republic was remembered positively mainly by the middle and the lower-middle classes. Entrepreneurs and unskilled workers were rather more reserved. In the sense of religious denomination, the best memoirs seem to prevail in the secular and Protestant parts of Czech society; the opinions of the Catholics were rather more mixed.

II

DISCOURSES ON THE FIRST REPUBLIC DURING THE COMMUNIST PERIOD

The communists, who seized power in 1948, seemed in the beginning to respect the legacy of the First Republic and Masaryk. Party leader and new President Klement Gottwald laid flowers on Masaryk's tomb

${ }^{8}$ Josef Harna, 'Nad reflexí první republiky v české společnosti po druhé světové válce (1945-1948)', in Lubomír Slezák (ed.), K poctě Jaroslava Marka: Sborník prací k 70. narozeninám prof. dr. Jaroslava Marka (Prague, 1996), 220.

${ }_{9}$ Abrams, The Struggle, 89. 
after his election in June 1948. In as late as 1950 (the centennial of Masaryk's birth), this event was still commemorated by the press; ${ }^{10}$ two leading communist ideologists, Václav Kopecký and Zdeněk Nejedlý (Masaryk's student, who authored a three-volume biography of the former president), published rather favourable texts on Masaryk. ${ }^{11}$

During this year however, the regime started the approaching Stalinisation campaign which culminated in the years 1952-3. The statues of Masaryk were removed from Czech towns (they had disappeared from Slovak towns already in 1939 and they were not re-established after the war), the town squares and streets were renamed; his books disappeared from libraries. Articles and pamphlets full of hatred began to appear. Particularly infamous was the publication Dokumenty o protilidové a protisociální politice T. G. Masaryka [The documents about the anti-people and anti-national politics of TGM].$^{12}$ Masaryk was characterised there by young Stalinist historians as a cosmopolitan, an enemy of the people, and a mouthpiece for the Czechoslovak bourgeoisie:

Those who believe that Masaryk brought us freedom, fail to believe in the historical power and strength of our people. ... To see the liberator in Masaryk and not in the people means not to believe in the deeds of our people and the people's democratic republic, ... it means to have an illusion about the western imperialists, ... from whose mercy Masaryk brought us the alleged freedom, and finally, it means disrespect to our nation and its glorious traditions. ${ }^{13}$

The communists with different opinions were forced to remain silent. For example, Nejedlý only succeeded in the re-publishing of the first two volumes of his Masaryk biography in the years 1949-50, the third volume could not appear.

The attacks on Masaryk and the First Republic multiplied. The prominent medium in this fight became the socialist-realistic novels depicting the interwar times. Books were written for this purpose; some other time, older, socially critical, First Republic novels were

10 'Sté výročí narození T. G. Masaryka', Rudé Právo (1950), 7 Jan., p. 1.

${ }^{11}$ Zdeněk Nejedlý, T. G. Masaryk ve vývoji české společnosti a československého stat (Prague, 1950); Václav Kopecký, T. G. Masaryk a komunisté (Prague, 1950).

${ }^{12}$ František Nečásek, Jan Plachta, and Eva Raisová (eds.), Dokumenty o protilidové a protisociální politice T. G. Masaryka (Prague, 1953).

13 Ibidem, 5. 
re-written in the socialist realistic style and republished. Such novels picture the First Republic mainly as a period in which class struggle was the principal and omnipresent social conflict, represented by stereotypical black and white characters on both sides: unemployed young workers, socially unreliable intellectuals, fat-cat factory owners in cylinders, spoiled bourgeois brats, and the like. The typical attributes of the First Republic included bourgeois villas, tabloids, prostitution, obscenity, beggars, hunger, unemployment, žebračenky (food stamps given to the unemployed who conducted public work), slums, executors and police shootings at workers' demonstrations. ${ }^{14}$ A very popular narrative was redemption of working men from the abyss of the lumpenproletariat by joining the real (communist) working class movement, or the saving of working people or intellectuals from social naivety, or a gradual decline and fall of bourgeois families.

Even a new name for the First Republic was created: the 'preMunich republic', which indicated that something which had ended in such an inglorious way could not have had much value by itself. The other new name was simply 'the bourgeois republic', implying that it was not a country of the people. Laying blame on the First Republic was especially the task of young journalists, historians and novelists, and it was primarily aimed at the youth, because "they have had no chance to experience the 'advantages and qualities' of the capitalist exploitation personally." 15 The most prominent example of this propaganda is the book Byla nám macechou: $O$ životě mládeže za první republiky [She was a stepmother for us: The youth in the First Republic], ${ }^{16}$ a collection of extracts from novels by prominent Czech authors, describing the negative experiences of youth during that time, with a preface written by President Gottwald.

${ }^{14}$ Interestingly, there is continuity not only between the Stalinist propaganda against the First Republic and that of the Communist Party of Czechoslovakia in interwar period, but also the right-wing propaganda from the so called 'Second Republic' (the territorially reduced Czecho-Slovakia existing between the Munich Agreement in September 1938 and the German occupation of the Czech lands of 15 March 1939). Also the Czech extreme right used to criticise at that time the overly large social inequalities, nepotism, disorder and corrupted parties; see František Kutnar, Generace brázdy (Prague, 1992), 192.

${ }^{15}$ Jiří Šubert, Fakta o postavení československé mládeže dříve a dnes (Prague, 1960), 3.

${ }_{16}$ Miroslav Červenka, Jarmila Mourková, and Milan Schultz, Byla nám macechou: O životě mládeže za první republiky (Prague, 1953). 
Nine different negative Stalinist narratives on the First Republic can be identified: (i) the Republic would never have come to existence without the Russian October Revolution; (ii) it was a bourgeois state, where the "people" ${ }^{17}$ were oppressed; (iii) the Czech bourgeoisie betrayed the people in Munich in 1938; (iv) Masaryk let the police shoot at the workers; (v) it was a country full of mess, political struggles, corruption and too many political parties; (vi) the state served to the rich only whereas the poor were starving; (vii) the Czechoslovak army became a tool of French imperialism in its crusade against the 'progressive forces'; (viii) mainly the youth were suffering: they could not get an education, were beaten by their masters in their apprenticeships and fell victim to unemployment while the golden youth were idling in jazz bars; (ix) the Social Democracy and People's Socialists betrayed the people hand in hand with the bourgeoisie.

The picture of the First Republic was clearly dichotomised in Stalinist discourse: there was only a space for the parasite capitalists and poor working-class people. The experiences of the lower classes were stressed while those of the middle class were marginalised. Another difference was that between the dark interwar times and the 'glorious', 'joyful' present; at the beginning of the 1950s, the prominent poet Vítězslav Nezval wrote in his poem praising the Prague Castle, the seat of the President of the Republic:

In the Prague Castle, you catch your breath, under the banner of the working-class President. The diplomats in cylinders, renters [men of leisure], life-time annuity, they have all disappeared. No longer has the Prague evening newspaper fabricated sensations and murders. The lazybone was replaced by the udarnik (strike worker), and tomorrow, everybody will be an udarnik. ${ }^{18}$

Another, less known poet Zikmund Skyba wrote a satirical poem Častuška o první republice [Chastushka on the First Republic]

${ }^{17}$ Stalinist propaganda used the term 'people' (lid) rather than the 'working class' (dělnická trída). It seems that the reason was the ambition of the regime to win over the majority of inhabitants to its side, and the identification with the 'people' was easier than with the less numerous 'working class'. More on the meanings of the category 'people' see Petr Fidelius, Reč komunistické moci (Prague, 1998); and Vladimír Macura, Štastný věk: Symboly, emblémy a mýty 1948-1989 (Prague, 1992).

${ }^{18}$ Vladimír Kovařík, Literární toulky Prahou (Prague, 1980), 145. 
(1954), ${ }^{19}$ accompanied by numerous caricatures ridiculing the Czech petty bourgeoisie nostalgically dreaming on the First Republic. The problematic periods, such as the political and economic crisis after 1918, the great depression and Munich, were stressed and the successes, such as the golden 1920s, were displaced. Life in the interwar period was thus characterised as "days filled with the infinite misery and suffering of thousands and millions of men, women and children." 20

An important question is why Czech Stalinism did not make the time of the Nazi occupation the main target of its attacks, as had been the case in the public discourse between 1945 and 1948? Firstly, it seems that the propagandist potential of the Nazi occupation was much lower, because it was condemned by almost everybody in the Czech society and the culprits were already gone. The enemies perceived by the communists as the most important in 1948 were not the Nazis but the 'Czech reaction', the First Republic political and financial elites, during the occupation either in exile in London or in the domestic non-communist resistance. Secondly, the First Republic, contrary to the Protectorate, divided Czech society into the communist and anti-communist 'halves'. The communists were using their propaganda against the First Republic as a tool to persuade, intimidate or defeat the hostile part of society. Thirdly, the Stalinists also needed to distinguish themselves from the period 1945-8, which was seen by them as characterised by struggle between the 'people' led by the communists and the 'reactionary forces' of the First Republic. According to the communist propaganda, the latter camp's wish was to re-establish the First Republic while the former aimed at continuing the building of the new people's democracy.

The response from a significant part of the society toward the Stalinist propaganda was to develop nostalgia for the First Republic. The sentiment was fuelled by the Czech broadcasting service of Radio Free Europe, but it was also a consequence of the difficulties of the 1950s, such as shortages of consumption goods, the 1953 currency reform which virtually destroyed the population's savings, the atmosphere

${ }^{19}$ Zikmund Skyba, At’ si kdo chce, co chce, říká ...: Častuška o první republice (Prague, 1954).

${ }^{20}$ Alexander Jandera and Alois Míka, Kapitoly z dějin predmnichovské republiky (Prague, 1953), 7. 
of fear and mass hysteria around political trials, the collectivisation and other processes and developments standing in sharp contrast to the still remembered peaceful interwar times. There were numerous ways in which the people nostalgic for the past tried to preserve the traditions of the First Republic. Some Czech families were still privately celebrating the 28th of October, the day Czechoslovakia was established in 1918, or Masaryk's birthday date, although these dates disappeared from the official calendar. There was also a habit of naming new-born sons Tomáš, after TGM. One of them (born four months after the communist coup d'état in 1948) recalls a day when his father called him 'Tomáš' in public, someone unknown walked up and told him that he had good parents. ${ }^{21}$

Even though there was a lot of regime propaganda against the First Republic, continuity was sustained in certain respects. The propaganda in the first years of his presidency called Gottwald the 'unifier' president - a clear reference to the president 'liberator' (Masaryk) and president 'constructor' (Beneš). Contrary to other communist countries, the function of the president of the republic was not abolished and the communist leaders generally sought to become the president, as was the case with Gottwald, Novotný and Husák. All of them first became heads of the Party and later combined the functions of Party chairman and president. There were only two exceptional situations: the first occurred after Gottwald's death in 1953 and resulted from his cult of personality (as no-one was seen to be able to replace him completely), and the second when, in the period following Novotný's downfall, known as the Prague Spring, Alexander Dubček was elected first secretary of the Party and Ludvík Svoboda became president. The communist regime kept the First Republic's national emblem and official name until 1960, the date Czechoslovak Socialist Republic was declared and the Hussite Pavise replaced the French-style emblem. The national flag and the national anthem were also maintained, unlike in many other communist countries.

During the late 1950s, as the process of de-Stalinisation proceeded, the rhetoric about the First Republic changed. Pamphlets, books and articles denouncing the First Republic appeared less often. Since the beginning of the 1960s, the first novelists, historians and journalists introduced less one-sided views. From 1963 onwards, the anniversary

${ }^{21}$ Tomáš Halík, Ptal jsem se cest (Prague, 1997), 29. 
of establishing the Republic was remembered regularly by the official media again. In 1966, it was stated that the 'pre-Munich' Republic was an advantageous base for the social struggles of workers, and it was not by chance that the working people internalised their democracy. ${ }^{22}$ The Stalinist narrative even became the target of satirists. One example is the story written at that time by two young popular Czech satirists, Jiří Grossman and Miroslav Šimek, titled 'How did my father send me to strike?'. The story ironically describes 'the hard life' of the past:

My father told me, with a tear in his eye, what it used to be like once. The land was mooched by the aliens and their domestic flunkies, champagne run in streams in the chateaus, the maiden pulled up their skirts, the prostitutes hung out on the boulevards, and delicatessen stores were mocking the streets with their prices in the filled up shop windows. Bata flooded the republic with his low quality shoes. He lured the customers on the low price and right after six years you could go for a new pair. ${ }^{23}$

During the Prague Spring of 1968, the Czech public looked for its inspiration on how to democratise the country and 'open it to the world' mainly in the history of the First Republic. There was a whole wave of interest in and nostalgia for the interwar period. The statues of Masaryk were renewed (similarly to 1945 and 1990) and his portraits were massively sold in the kiosks. ${ }^{24}$ The new popular monograph on him (fifteen years after the publication of Nejedly's work), T. G. Masaryk by Milan Machovec, emphasised the pro-socialist aspects of his thinking - and sold tens of thousands of copies immediately. Czech historians openly protested against the claims published fifteen years ago in the above mentioned collection of documents (Dokumenty o protilidové ...) that in 1918 Masaryk financed an attempt to assassinate Lenin (the Savinkov affair), which is, ironically, considered true by contemporary historians. ${ }^{25}$

The new president Ludvík Svoboda laid flowers on Masaryk's grave for the first time since Gottwald made this gesture in 1948, and for the last time until 1990, when Václav Havel did the same. Reinstatement of the First Republic emblem was discussed, as was removal of the

${ }^{22}$ Jan Fojtík, '28. ř́jen', Rudé Právo (1968), 28 Oct., p. 1.

${ }^{23}$ Miloslav Šimek and Jiří Grossmann, Povídky aneb nechci slevu zadarmo (Prague, 1997), 63.

${ }^{24}$ Orzoff, Battle for the Castle, 216.

${ }^{25}$ Alain Soubigou, Thomas Masaryk (Paris, 2002). 
word 'socialist' in the country's name. The positive reaction to the Prague Spring in Romania and Yugoslavia was interpreted as an echo of the Little Entente. A public opinion poll of October 1968 asked the question: "Which period in our history do you consider the most glorious?" The First Republic scored in first place (38\%) over the Hussite period $(36 \%)$, even though the latter had been highly glorified by the regime in the previous two decades. This was a clear improvement in comparison to the results of the sociological research of $1946 .{ }^{26}$ Even the 'liberal' communists accepted the positive picture of the First Republic; although they were trying to avoid an uncritical view of that time. An example is the writer Jan Procházka, who claimed that "although it [the First Republic] was based on noble ideals, these were quite often violated"; and that "there were many social problems." ${ }^{27} \mathrm{He}$ saw one of the most positive aspects of the First Republic in the fact "that it did not violate the dignity of the political prisoners." 28

The end of the Prague Spring and the events of 1938-9 were compared: the meetings of the leaders of the Warsaw Pact countries were paralleled to the meetings of the European statesmen in Munich 1938. Svoboda's visit to Moscow after the invasion of August 1968 was compared with Emil Hácha's visit to Berlin in March 1939, confirming the final destruction of interwar Czechoslovakia. ${ }^{29}$ During the first anniversary of the Warsaw Pact invasion, appeals circulated to boycott public transportation as a sign of protest, similarly as at the first anniversary of the Munich Agreement.

'The normalisation regime' partly reintroduced the Stalinist interpretation of First Republic, though with some changes. A typical Stalinist cliché about the heroic communist party leading the working class and the betraying bourgeoisie reappeared in textbooks, journals, and movies, but there was a complete silence around Masaryk this time. The regime obviously did not dare to repeat the Stalinist denunciations. Also, the Munich betrayal was primarily interpreted as the responsibility of the West and not of the Czech bourgeoisie, as opposed to what was said in the 1950s; the writer Karel Capek,

${ }^{26}$ Čeněk Adamec et al., Vztah Čechů a Slováků k dějinám (Prague, 1968), 8.

${ }^{27}$ Jan Procházka, Politika pro každého (Prague, 1991), 264.

${ }^{28}$ Ibidem, 265.

${ }^{29}$ Mary Heimann, Czechoslovakia, the State that Failed (New York, 2009), 258. 
a friend of Masaryk, remained praised as 'an important representative of antifascism', although he was displaced during the 1950s. Some of the most discredited terms such as 'cosmopolitism', 'everlasting misery', 'betraying clique', and the like, disappeared.

On the other hand, in the 'normalisation' novels and films dealing with the First Republic we can find a broader variety of narratives than just class struggle and a more colourful spectrum of social characters. The regime tolerated this, because the nostalgia for the First Republic in popular culture seemingly did not motivate the public toward anti-regime political actions anymore, but rather, as a certain form of entertainment, contributed to the pacification of the society. The most prominent example among the novels of the time is the book by Ota Pavel, Smrt krásných srncu [Forbidden dreams] (1971), filmed in $1986 .{ }^{30}$ The central character - the author's father - is not a worker but a Jewish commercial traveller selling fridges and making good money. The First Republic is described idyllically, even the names of the leading politicians are mentioned in a neutral way, and typical official attributes of the First Republic (unemployment, hunger etc.) are not present. Politics, however, remains a taboo in this book and the author was forced to modify the passage telling a story of the main character's buying a bust of Masaryk at the time of the destruction of Czechoslovakia: in the final version, "a beautiful Czech bust" was featured. The first TV series emphasising the nostalgic picture of the First Republic is the Hřřšni lidé města pražského [Sinful people of the town of Prague] (13 series followed by four films by Jiř́ Sequens, 1968, 1970-1), about the First Republic's criminal police. The inspectors are no longer pictured as 'tools of bourgeois class justice' but rather as sympathetic professionals dealing with the Prague underworld. Prague does not resemble much of the city from the interwar period but rather from the turn of the century, which strengthens the nostalgic view. The communists, proletariat and capitalist are absent in this world. On the other hand, if a movie contained a political plot, it was necessary to present the interwar time negatively, as in the TV series Gottwald (Evžen Sokolovský, 1986), or in the TV series combining a political story with everyday life (Synové a dcery Jakuba Skláre [Jakub Skláŕrs sons and daughters], Jaroslav Dudek, 1985).

30 Ota Pavel, Smrt krásných srnců (Prague, 1971). 
The first signals of the upcoming change in the political interpretation of the First Republic were detectable from the beginning of the perestroika. The film version of the already mentioned book by Ota Pavel, adapted by Karel Kachyňa in 1986, showed the bust of Masaryk. The first president appeared as a character for the first time in the abovementioned TV series Gottwald (1986) and was represented in a remarkably neutral way. On the anniversary of Masaryk's death in 1987, the Party's official press organ Rudé Právo published a rather sympathetic article on him, written by a leading regime historian. ${ }^{31}$ The 28th of October was reintroduced as a national holiday, 'the establishment of independent Czechoslovakia', in 1988, and Masaryk's name was even positively mentioned in a communist functionary's speech during the rally on that day. ${ }^{32}$ In the same year, a popular booklet T. G. Masaryk a vznik ČSR [Masaryk and the establishing of Czechoslovakia] by Jan Galandauer was issued (with a photograph of TGM on the cover) and sold out on the spot. ${ }^{33}$ The film about the life of Karel Čapek (Člověk proti zkáze [A man against the destruction], by Štepán Skalský and Vladimír Pleskot, 1989), again showed Masaryk as one of the characters (represented this time in a very idealised way), but the premiere came one month after the Velvet Revolution in January 1990, and its impact therefore remained limited. On the other hand, schoolbooks and official monographs did not change their view on First Republic politics until 1990.

Dissident writings about the First Republic were prevailingly positive during the 1970s and 1980s. In the 1980s, we can find attempts to interpret the First Republic by the liberal-conservative part of the dissident movement as "a good, old society before the rule of the mob" while the left-inclined part insisted on a "socially progressive' character of the country. An example of the positive liberal-conservative interpretation is to be found in the collection of essays by Jiři Kroutvor, Potiže s dějinami [Difficulties with history] (1990; written in 1980). While the author does not mention social inequalities as Procházka had done ten years before, he stresses the

31 Jan Galandauer, 'K výročí T. G. Masaryka', Rudé právo (1987), 14 Sept., p. 3.

32 Karen Gammelgaard, 'The Discursive Battle in 1988 over the Czechoslovak State Holiday 28th October', in Scando-Slavica, lvii, 1 (2011), 54.

33 Jan Galandauer, T. G. Masaryk a vznik ČSR (Slovo k historii. Sešity k poznání nár. Minulosti, 14, Prague, 1988), 14. 
"elegance, fine culture, respect, culture of speeches, sense of honesty and life optimism" 34 as defining the style of the First Republic. In another essay, he admires a men's magazine from that time propagating modern lifestyles such as skiing, swimming, motoring, hygiene, mixed drinks and practical sport suits. ${ }^{35}$ According to him, such a lifestyle was "crucial for the establishment of the real elite". The First Republic had the natural and cultivated elites who were "the object of frustrated envy and hatred by the average individual". ${ }^{36}$ The same interpretation of the First Republic was offered by Pavel Tigrid, another important Czech émigré author (later, an advisor to President Václav Havel and Czech minister of culture), in 1988: "Civilised relationships among the people, a commonly acknowledged scale of values, a modest but not inferior national self-confidence, respect for traditions, good schools, clean trains and pubs with polite service". ${ }^{37}$ Interestingly, it had been precisely the dirty pubs that were mentioned by the extreme right-wing anti-republican propaganda of 1938-9 in its criticism of the First Republic. ${ }^{38}$ There were also attempts by a small Catholic faction of the Czech dissident movement to blame the First Republic for being militantly secular and chauvinist, systematically oppressing the rights of its national minorities and Catholics. The Catholic conservative Ladislav Jehlička, who claimed that the withdrawal of Czechoslovakia from Europe did not start in 1948 or 1945 , but as early as in 1918 , is an example. ${ }^{39}$ His views were nonetheless refused by both liberal and the socialist members of the dissident movement. ${ }^{40}$

${ }^{34}$ Jiří Kroutvor, Potiže s dějinami (Prague, 1990), 17.

${ }^{35}$ Ibidem, 31.

${ }^{36}$ Ibidem, 44.

${ }^{37}$ Pavel Tigrid, Kapesní průvodce inteligentní ženy po vlastním osudu (Toronto, 1988), 20-1.

${ }^{38}$ Jan Rataj, $O$ autoritativní národni stát. Ideologické proměny české politiky $v$ druhé republice, 1938-1939 (Prague, 1997), 142.

${ }^{39}$ Ladislav Jehlička, Kř̀ik koruny svatováclavské (Prague, 2010), 14.

${ }^{40}$ Martin Schultze Wessel, 'Stř̌ed je na západě: stř̌ední Evropa v české diskusi 80. let', in Eva Hahnová (ed.), Evropa očima Čechů. Sborník ze symposia konaného $v$ centru Franze Kafky ve dnech 22.-23. ř́ijna 1996 (Prague, 1997), 79. 


\section{III}

\section{POST-COMMUNIST DISCOURSES ON THE FIRST REPUBLIC}

The Velvet Revolution in November 1989 brought about a full rehabilitation of the First Republic in the Czech public discourse, in a way similar to the Prague Spring of 1968. According to Peter Bugge, "admiration of the First Republic became an almost obligatory element of the public discourse and scholarly works". ${ }^{41}$ Extraordinarily strong was the discourse in the Czech part of the Federation in the first months after the Velvet Revolution, before the conflicts between the Czech and Slovak political representations problematised the entire idea of Czechoslovakia. ${ }^{42}$ Czech towns massively renewed the statues of Masaryk in 1990, main streets and squares were renamed after him and Beneš, and publishing houses were producing books by and on Masaryk and on the First Republic in hundreds of thousands of copies. The highest decorations of the Czechoslovak Federation appeared alongside the already-existing Order of the White Lion, the Order of Tomáš Garrigue Masaryk and the Milan Rastislav Stefanik Order (Masaryk's Slovak collaborator). In 1994, the Order of Masaryk was made the highest state award of the independent Czech Republic. The University of Brno assumed the name of Masaryk again. Historians, journalists and filmmakers rushed to make their works on Masaryk and the First Republic; even LPs with Masaryk's favoured songs gained some popularity. ${ }^{43}$ Czech political parties stylised themselves as the inheritors of the First Republic traditions (the social democrats held their press conferences under the portrait of TGM, the People's Socialists used the portrait of Beneš on their electoral posters). The new national emblem regained its old shape, now with a bigger space for Slovakia. The Czechoslovak and later the Czech constitutional system was modelled on the First Republic tradition (a president

41 Bugge, 'Czech democracy', 28.

${ }^{42}$ Interestingly enough, the division of Czechoslovakia did not by itself really affect the positive image of the First Republic in the eyes of Czechs. The newly established Czech Republic was still perceived as a continuation of Masaryk's Czechoslovakia. Symbolically, the Czech political elites decided to keep the flag of Czechoslovakia for the Czech Republic. For 'the misfortune' of Czechoslovakia, there were Slovaks who were seen responsible rather than the ideas of Masaryk.

${ }^{43}$ Masaryk's words: "Democracy is the guarantee of peace for us and for the world" appeared on the front page of Literární noviny (1990), 12 April, p. 15, a supplement of Lidové noviny (a major Czech daily). 
elected by the parliament, proportional electoral system, Senate reinstated by the Czech constitution since 1993). The 28th October has remained a national holiday in the Czech Republic after the country's division, although not in Slovakia, where it is commemorated only as 'a distinguished day'. Even the eight-year grammar school has been reintroduced as a resumption of the most appreciated part of the First Republic school system, with, i.a., a separation of more and less talented pupils already at the age of 10 or 11 , despite the tendency to standarise elementary education, present in many Western countries from the 1960s onwards. (The re-establishment of eight-year grammar schools was justified as a way of developing the natural elite, which is necessary in a free and democratic society.) In municipal administration, the communist terminology (national committee, chairman of the national committee) was replaced by the pre-war names (local council, mayor).

Leading representatives of the new political powers articulated the need to follow First Republic traditions. Václav Havel's speeches on the radio were named Hovory z Lán [Talks from the Lány], in a clear reference to Čapek's Hovory s TGM [Talks with TGM] (1928-35). ${ }^{44}$ Havel let himself be photographed sitting on a horse in Lány; the picture was widely distributed, although this was probably the first time he sat on horseback. The photograph was a clear reference to Masaryk who was often photographed in Lány mounted on his horse. He also used Masaryk's car during his first swearing-in ceremony. In Havel's words the First Republic was characterised by "the rule of law, orientation on western liberal civilisation, tolerance, politeness, humanity and responsibility for public affairs." 45 Havel obviously downplayed the pro-Slavic, nationalist, anti-clerical ideology of the interwar times. He also disregarded the fact that the political discourse at that time had imbued the words such as 'liberal' or 'liberalism' a negative meaning, associating them with the unregulated capitalism that had once led to WWI. Similarly, the ideas of TGM were interpreted by Havel as anticipating and pursuing European integration, although with a more accurate look we can see that

${ }^{44}$ Lány Castle was the favourite residence both of Masaryk and Havel.

${ }^{45}$ Václav Havel, 'Státní svátek České republiky, Vladislavský sál Pražského hradu, 28.10.1993', in idem, Projevy a jiné texty $z$ let 1992-1999, vol. 7 (Prague, 1999), 152-3. 
Masaryk's idea of European integration was much looser than the current EU project. ${ }^{46}$

Also, Václav Klaus, the Czech finance minister (1990-2) and prime minister (1992-7) often referred to the First Republic in his speeches and articles. Due to his professional position, he stressed its economic achievements, rather than 'spiritual and moral values'. Just as Havel's admirers compared him with Masaryk, Klaus, as a minister of finance, was often compared with Alois Rašín, the first minister of finance after 1918, whose anti-inflation policy was well known. Klaus saw himself as part of this continuity:

We need a positive economic ideal in order to move from waiting to activity ... to overcome all the irrationalities of the old regime, and 'the laziness of the mob' (in the terminology of Alois Rašín) ... only in this way can we, in a nervous and emotionally unstable Eastern and Central Europe, create an island of order and normality. ${ }^{47}$

Klaus also compared the political opposition to the interwar communists, because they "consciously play on the worse aspects of the personality of each of us, such as greed, suspiciousness, negativism, distrust in ourselves, in our powers and abilities." 48

The First Republic has been seen in the post-communist public discourse as a clear antithesis to the communist regime. Everything was different and better compared to socialism. Due to the discrediting of all leftist ideas under communism, some of the First Republican traditions have not been renewed - only to mention the three most important ones: the Ghent system, the workers' councils and the governmental support to cooperatives. They were not reintroduced, although the Ghent system exists in Sweden, Denmark and Finland, the Betriebsräte function in Germany and Austria, and there is a strong co-operative sector in most Western countries. Occasionally, even 'the social democratic tendencies' of the First Republic ${ }^{49}$ were warned against in the circles of neoliberal journalists. Also, positive conservative

${ }^{46}$ Peter Bugge, 'České obrazy Evropy za první republiky', in Hahnová (ed.), Evropa očima Čechů, 97-9.

${ }^{47}$ Václav Klaus, O tvář zítřka (Prague, 1991), 36-8.

${ }^{48}$ Idem, Obhajoba zapomenutých myšlenek (Prague, 1997), 147.

${ }^{49}$ Dan Hrubý, 'Sladké návraty: za vzýváním první republiky stojí často osobní zájem', Reflex, 22 (1994), 11. 
interpretations of the First Republic continued to exist. They showed the First Republic as the counter-thesis to communist 'collectivism', a time of intact families, wives taking care of their children at home, harmonious relations between employers and employees, wellfunctioning family farms in the countryside, and a modest lifestyle without "socialist greed and consumerism"..$^{50}$

In the post-communist narratives, the society of the First Republic has been, contrary to the Stalinist dichotomisation, seen through the prism of the middle-class's well-being and, especially, the hard experience of workers and the rural poor began to be displaced. The lifestyle of the middle class (about a third of the population at that time) has been declared universal and the experiences of both urban and rural workers, generally the lower classes marginalised. An example of this can be found in the school textbook, ĆSR 1918-1939, where it is claimed that at that time "most of the married women did not work and had enough time to devote to their families; in many cases, they had a servant girl." ${ }^{11}$ In fact, this was the case for no more than 10 per cent of Czech families. Another claim is that "the weekend family walk, with the children dressed up in sailor-suits", and "having lunch in a cheap restaurant" was a typical leisure activity. According to the textbook, holidays were spent in the countryside with relatives, or in one of "the cheap guesthouses or B\&Bs."52 Again, this is a description of a lifestyle affordable for no more than the upper third of the urban society. In similar publications, the First Republic is full of small shops and workshops with skilled and kind personnel. The years of prosperity are put forward, while the years of depression are mentioned to a much lesser extent than in the communist picture of the First Republic.

There has been, however, a broader consensus about the two crucial characteristics of the First Republic which are considered undesirable. First, there is an extremely fragmented political landscape with a proportional electoral system without any threshold. A percentage threshold was introduced in post-communist Czechoslovakia, and it was transferred into the legal systems of the Czech Republic

${ }^{50}$ Pavel Bělina et al., Dějiny zemí koruny české. Od nástupu osvícenství po naši dobu (Prague, 1992), 308.

${ }^{51}$ Pavel Augusta and František Honzák, ČSR 1918-1938 (Prague, 1991), 24.

52 Ibidem, 25. 
and Slovakia. The other trait is the multi-ethnic character of the First Republic, with Czechs making up only a half of the population. There has also been a broader consensus on the impossibility of giving back citizenship and property to the former German citizens. Although Václav Havel expressed his regret over their expulsion during his first state visit to Germany in 1990, the possibility of returning German property remained unacceptable. The Sudeten Germans were seen as those who had destroyed the beloved First Republic, the traditions of which the post-communist Czechs aimed to partly re-establish.

A critical attitude to the First Republic in the Czech post-communist discourse was mainly expressed by three different groups. The first consisted of the Czech communists, a parliamentary party with an electoral potential of about 10-15 per cent. They acknowledged the establishment of an independent Czechoslovakia in 1918 and the positive role of Presidents Masaryk and Beneš. Praise for the latter was connected with the communists' nationalist position toward 'the Sudeten German danger'. Beneš was seen by them as a politician who had 'solved' this problem. On the other hand, the Czech communists aimed at preserving the negative aspects of the First Republic in historical memory, mainly unemployment, huge social inequalities and backwardness of the countryside. Only the Stalinist wing of the party was hesitant to accept Masaryk and the First Republic as such. One example is the rally organised by a tiny group of Stalinist youths at the unveiling of the Masaryk statue at Prague Castle on 7 March 2000. The youth rallied under the slogan of the First Republic's communists 'Not Masaryk but Lenin'. The party, however, condemned this rally in their internal discussions.

While the conservative Catholics and anti-nationalist liberal intellectuals have not enjoyed electoral support similar to that of the communists, they have been influential in the mainstream media. The Catholic conservatives referred to the tradition of their grouping in the interwar state, emphasising their sympathies towards Sudeten Germans and Habsburgs (in the First Republic, Catholics identified themselves rather with Czech nationalism and antisemitism). They perceived the First Republic as godless, socially progressive and too egalitarian, inspired by Protestant and Hussite traditions, and even as the radicals from this camp claimed - as a project condemned to failure from the beginning. According to them, with the destruction of the Habsburg monarchy and the campaign against the Catholic 
Church, Masaryk and Beneš opened the door to the Czech-German conflict, the expulsion of Germans after 1945, and finally, to the communist rule. One member of this group, gathered around the journal Střední Evropa and a small Christian Democratic Party, was Rudolf Kučera; at the time of the Czech and Slovak split in 1992, this author wrote that "the establishment of the Czechoslovak state [in 1918 SH's note] had unfortunately been a hopeless project, with a dead end." ${ }^{3}$ According to him, the new Czech Republic should renew the traditions of the common existence of Czechs, Germans and Jews in Bohemia, rather than those of the First Republic, and cooperate with Austria and Hungary. The second group, the anti-nationalist liberals, condemned the First Republic for the discrimination of German minority. The leading voice of this group, a dissident and journalist, Bohumil Doležal, claimed, for instance, that the state had been "modern, democratic, liberal, based on the European values, but it turned its kind face mainly to the Czechs." 54

Both groups soon gained the image of forces representing the interests of Sudeten Germans' refugee organisations, and were rejected by almost the whole Czech political spectrum. Even Václav Havel, who had once expressed his refusal of "certain nationalist aspects" of the First Republic and for its "reluctance to build Czechoslovakia as a state of all citizens", ${ }^{55}$ criticised them: "If somebody claims ... that the Czechoslovak Republic ... was a mistake and the reason of later catastrophes, he is only showing his own ignorance." ${ }^{56}$

The Catholic conservative and anti-nationalist liberal camps' inability to influence public opinion on the First Republic is illustrated by the fact that the public did not come to admire the Habsburg monarchy or condemn the expulsion of Sudeten Germans. Results of public opinion research show that the Habsburg monarchy does not rate high among the 'glorious periods' in Czech national history. 'The era of Franz Joseph I' scored only 2 per cent in 2008 among the most successful periods in Czech history, though one should possibly

${ }^{53}$ Rudolf Kučera, Komentáre. Politické analýzy $z$ let 1990-1992 (Prague, 1993), 109.

${ }^{54}$ Bohumil Doležal, 'Co patří do historie', Respekt (1995), 27 Feb., p. 2.

${ }^{55}$ Václav Havel, 'Projev k 55. výročí Mnichova, Praha, 29.9.1993', in idem, Projevy, 128.

${ }^{56}$ Idem, 'Češi a Němci na cestě k dobrému sousedství, Praha 17.2.1995', in ibidem, 362. 
note that this category was missing in the polls of 1946, 1968 and even 1992. ${ }^{57}$ Also, the Sudeten German demands have been refused by a majority of the Czechs. Their ethnic rights in the First Republic are seen as sufficiently respected, their expulsion after 1945 justified and the contemporary property demands groundless.

Interestingly enough, the interwar and Protectorate-period Czech fascist discourse on the First Republic as a creation of 'Jews and Masons' does not play any part in the post-communist narratives. It exists only in the marginal, extreme right-wing Catholic journals such as the Týdeník Politika which, in 1991, published a collection of articles characterising Masaryk as a puppet in Jewish hands. ${ }^{58}$ On the contrary, the Republican Party, the main force of the populist right, admires Masaryk and the First Republic, pursuing the death penalty and repressive politics against the Romani with the justification that they used to exist in Masaryk's republic. ${ }^{59}$

However, during the last two decades, the First Republic has slightly lost its popularity: in a 1992 public opinion research, the First Republic was no more loved to the extent it had been loved in 1968 , and, with a 23 per cent vote, it was placed behind the reign of Charles IV (29\%). The First Republic has subsequently always come second in the opinion polls ever since, with a slight negative tendency - scoring 19 per cent in 2008, after Charles IV's time (40\%). The possible explanation seems primarily not to be the impact of conservative or anti-nationalist liberal critiques but rather the fact that personal experience of that time became a rarity (the research has shown an extraordinary popularity of the First Republic among the older generation). Another explanation might be the proverbial postmodern mentality of the contemporary Czech society, which does not see history as a legitimising power in actual political struggle but prefers the romantic narrative of the high medieval period, of cultural blossoming, without an impact on contemporary political struggles.

57 Pfeiferová and Šubrt, 'Veřejné mínění', 16.

58 Jan Příhoda, 'T. G. Masaryk - studie vyvolencovy krycí legendy’, Týdeník Politika (1991), September, <http://www.spiknuti-proti-cirkvi-a-lidstvu.com/ literatura/Studie_vyvolencovy_kryci_legendy_Masaryk.pdf $>$ [Accessed: Nov. 10, $2014]$.

59 'Bereme si příklad z první republiky? Masaryk a cikáni', Republika (1995), 26 June-2 July, p. 6. 
Table 1. The most glorious period in Czech history (based on polls conducted in 1946-2008)

\begin{tabular}{|c|c|c|c|c|c|c|c|}
\hline 1946 & & 1968 & & 1992 & & 2008 & \\
\hline Period & $\begin{array}{l}\text { Per } \\
\text { cent }\end{array}$ & Period & $\begin{array}{l}\text { Per } \\
\text { cent }\end{array}$ & Period & $\begin{array}{l}\text { Per } \\
\text { cent }\end{array}$ & Period & $\begin{array}{l}\text { Per } \\
\text { cent }\end{array}$ \\
\hline Hussites & 19 & $\begin{array}{l}\text { First } \\
\text { Republic }\end{array}$ & 39 & Charles IV & 29 & Charles IV & 40.6 \\
\hline Charles IV & 17 & Hussites & 36 & $\begin{array}{l}\text { First } \\
\text { Republic }\end{array}$ & 23 & $\begin{array}{l}\text { First } \\
\text { Republic }\end{array}$ & 19.4 \\
\hline $1945-6$ & 16 & Charles IV & 31 & Hussites & 9 & $\begin{array}{l}\text { National } \\
\text { awakening }\end{array}$ & 7.6 \\
\hline First Republic & 8 & $\begin{array}{l}\text { After January } \\
1968\end{array}$ & 21 & After 1989 & 4 & Hussites & 6 \\
\hline St. Wenceslas & 8 & $\begin{array}{l}\text { National } \\
\text { awaking }\end{array}$ & 15 & $1948-89$ & 3 & $\begin{array}{l}\text { Great } \\
\text { Moravia }\end{array}$ & 5.3 \\
\hline $\begin{array}{l}\text { George of } \\
\text { Poděbrady }\end{array}$ & 7 & $1945-8$ & 9 & $1945-7$ & 2 & Přemyslids & 3.2 \\
\hline $\begin{array}{l}\text { National } \\
\text { awakening }\end{array}$ & 3 & $\begin{array}{l}\text { George of } \\
\text { Poděbrady }\end{array}$ & 5 & $\begin{array}{l}\text { National } \\
\text { awakening }\end{array}$ & 2 & $\begin{array}{l}\text { George of } \\
\text { Poděbrady }\end{array}$ & 2 \\
\hline
\end{tabular}

Source: Štěpánka Pfeiferová and Jiři Šubrt, 'Veřejné mínění o problematice českých dějin', Naše společnost, vii, 2 (2009), 16-22.

\section{IV \\ CONCLUSION}

The reference to the First Republic played an important role in the Czech political history in the second half of the twentieth century. The Stalinist regime aimed to use the First Republic as its antithesis, and made it the main target of its propaganda. However, there was also a non-dogmatic tradition within the communist movement, which came to the fore in the years 1935-8, 1945-8 and in the 1960s, interpreting the First Republic less intransigently and adapting it for the purposes of reformist communism. Although the First Republic had been discredited after 1938, part of the public started to express nostalgia toward it during the war and particularly in the 1950s. This was mainly because of the repressive character of the Stalinist regime, which created sharp contrast to the interwar times. The younger generation generally tended not to believe the communist propaganda and adopted the same view after the end of Stalinism. 
The year 1968 marked the peak of the First Republic nostalgia, this time both in the public opinion and in regime propaganda. 'The normalisation regime' tried to bring back some elements of the negative image of the First Republic, mainly in political history, while in popular culture it could remain nostalgic. The political image of the First Republic began changing in the years of perestroika in favour of more positive interpretations that allowed partial public reappearance of Masaryk. Dissident writings included a variety of positions toward the First Republic, from the positive majority (socialist, liberal or even conservative interpretations) to the negative Catholic conservative interpretations.

The Czech mainstream public discourse adopted a highly positive image of the First Republic again in 1990. This time it had been used as a legitimising tool for political and economic reforms. The independent Czech Republic decided in 1993 to claim the legacy of the First Republic, and the Catholic conservative voices - calling for renewal of the medieval Christian traditions of Saint Venceslas or Saint Adalbert - remained marginal. However, the legitimising potential of the interwar Republic weakened considerably after the first years of social transformation, as a result of, either, the dissolution of Czechoslovakia or the disappearance of generations that had first-hand experience of the First Republic - or even as a result of pro-Catholic, anti-nationalist, pro-German and pro-Habsburg interpretations of Czech history, as present in the media (which have been labelled negativist by their opponents). ${ }^{60}$ The lack of mobilising potential of the First Republic is especially obvious compared to the contemporary struggle over the communist past. ${ }^{61}$ Although there have been several polemics over the First Republic, ${ }^{62}$ their intensity cannot be compared

${ }^{60}$ Miloslav Bednář (ed.), Spory o dějiny. Sborník kritických texti̊, i (Prague, 1999).

${ }^{61}$ Ondřej Slačálek, 'Český antikomunismus jako pokus o obnovu hegemonie', in Britské listy (2009), 22 June, <http://blisty.cz/art/47533.html> [Accessed: Nov. 15, 2014].

${ }^{62}$ Of Czech historiography, worth mentioning is the polemic on the study by Podiven [Petr Pithart], Češi v dějinách nové doby (1848-1939) (Prague, 1990); also, Antonín Klimek, Boj o Hrad: vnitropolitický vývoj Československa 19181926 na půdorysu zápasu o prezidentské nástupnictví (Prague, 1996); or, recently, Heimann, Czechoslovakia. It seems that in most contemporary academic writing on interwar Czechoslovakia (both Czech and international), a critical mood prevails, seeing its nationalities policies as the state's main weakness. 
to the discussions on the expulsions of Germans or communism, and the positive image of the First Republic has remained consensual. Today, it is no more a matter of big public discussion, and it mainly survives as a rather formal symbol of Czech statehood (with regular celebrations of the 28th of October).

proofreading Tristan Korecki 